\title{
A infância excepcional na história e na historiografia: levantamento de referencial e estudo do estado da arte
}

$\underline{\text { Izabela Gomes Moretti (IC) }}$

\begin{abstract}
Resumo
Esta pesquisa tem a finalidade de produzir um levantamento da produção acerca da história da educação especial e da criança excepcional. Focaliza a criança com deficiência intelectual, procurando compreender o estado da arte da produção historiográfica. A análise articula procedimentos quantitativos a metodologias qualitativas de estudo da produção inventariada. Vale-se das pesquisas de Michel Foucault sobre a história da loucura e a ordenação social dos discursos para conduzir uma reflexão a respeito da maneira como a temática da criança excepcional e da sua escolarização vem sendo tratada pela historiografia.
\end{abstract}

Palavras Chave: Educação Especial, Infância Excepcional, História da Educação e Historiografia

\section{Introdução}

Esta pesquisa procurou inventariar a produção histórica sobre o tema da escolarização da infância excepcional. Portanto, ocupou-se do levantamento bibliográfico sobre a história da educação para crianças com deficiência intelectual. Para além das instituições e dos programas de atendimento, perguntou pelos sujeitos atendidos buscando compreender em que medida as suas histórias aparecem na composição do material levantado.

\section{Resultados e Discussão}

Partindo das bases de dados digitais das bibliotecas da USP, UNICAMP, UNESP, PUC-SP, UNIFESP, UFRJ, UERJ, UFF, PUC-RJ e UFMG a busca foi filtrada com os seguintes assuntos: "Educação Especial no Brasil", "História da Educação Especial" e "Educação Especial". Do resultado obtido, retiramos todos os livros que tinham cunho psicológico/médico e, também, quando se trata de especificidades como surdez, autismo entre outros distúrbios e/ou deficiências. Buscou-se selecionar apenas as referências que falam sobre a história e formação de conceitos referentes à Educação Especial e ao indivíduo considerado especial.

O levantamento da produção acerca da história da educação da criança excepcional e o estudo do seu estado da arte pretendeu contribuir para desenvolver as linhas de pesquisa "políticas educacionais e discursos especializados" do Grupo História da Escolarização no BrasilUFRGS/USP/UNICAMP. Esse esforço de mapeamento da produção teve a finalidade de auxiliar na pesquisa sobre as interseções entre os discursos higienista, médico e o da psicologia com o discurso educacional que ora ocupam as preocupações deste grupo.

\section{Conclusões}

O levantamento serviu para identificar a forma incipiente como a história da educação tem tratado o tema e indicar o protagonismo da Faculdade de Educação da Unicamp, local inicial do levantamento, nessa área. Os trabalhos de conclusão de curso de Higa (2001) e Moreira (2003) foram parte dos resultados de um conjunto de orientações conduzidas por Heloisa Helena Pimenta Rocha (2003) no âmbito do discurso médico-higienista em São Paulo. Assim, o levantamento da produção na área da história da educação da criança excepcional que este projeto permitiu relacionar dois núcleos de pesquisa que já vêm investigando esse tema de modo mais sistemático.

\section{Agradecimentos}

Este trabalho contou com financiamento PIBIC.

HIGA, Renata Juliana. A educação especial nas décadas de 1920 e 1930 através da Revista de Educação. Trabalho de Conclusão de Curso (Graduação em Pedagogia). Campinas: Unicamp, 2001. 77p. JANNUZZI, Gilberta. A educação do deficiente no Brasil: dos primórdios ao início do século XXI. $3^{\mathrm{a}}$ Ed. Campinas: Autores Associados, 2011.

A luta pela educação do deficiente no Brasil. $2^{\mathrm{a}} \mathrm{Ed}$. Campinas: Autores Associados, 1992.

MOREIRA, Lucirléia Alves. A produção social da anormalidade: um estudo sobre a Liga Brasileira de Higiene Mental na década de 1920. Trabalho de Conclusão de Curso (Graduação em Pedagogia). Campinas: Unicamp, 2003.

ROCHA, Heloisa Helena Pimenta. A higienização dos costumes: educação escolar e saude no projeto do Instituto de Hygiene de São Paulo (1918-1925). Campinas, SP: Mercado das Letras: São Paulo: FAPESP, 2003. 